\title{
Controlled trial of chlorpromazine as antisecretory agent in patients with cholera hydrated intravenously
}

\author{
G H RABBANI, W B GREENOUGH III, J HOLMGREN, B KIRKWOOD
}

\begin{abstract}
A randomised controlled trial was conducted to investigate the ability of chlorpromazine to reduce intestinal secretion in cholera. Chlorpromazine had reduced loss of intestinal fluid in animals with diarrhoea induced by cholera toxin, and in a preliminary study the drug had reduced purging in patients with cholera.

Forty-six adults with cholera were included in the randomised trial. Of these, 34 were treated with chlorpromazine $(1 \mathrm{mg} / \mathrm{kg}$ or $4 \mathrm{mg} / \mathrm{kg}$ either by mouth or intramuscularly) and 12 served as controls. After treatment with the drug there was a significantly greater reduction in the rate of fluid loss in the treated patients than in the controls during the first $(p<0.005)$, second $(p<0.05)$, and fourth $(p<0.01)$ eight-hour periods but not during the third eight-hour period; the dose of $4 \mathrm{mg} / \mathrm{kg}$ was only marginally more effective than $1 \mathrm{mg} / \mathrm{kg}$. The effect of chlorpromazine was strikingly biphasic, with one peak during the first eight hours and another 24-32 hours after administration. Chlorpromazine also significantly reduced the duration of diarrhoea, frequency of vomiting, and amount of intravenous fluid required. The drug induced mild sedation and no hypotension in these wellhydrated patients.
\end{abstract}

International Centre for Diarrhoeal Disease Research, Bangladesh (ICDDR, B), GPO Box 128, Dacca-2, Bangladesh

G H RABBANI, MSC, DPH, assistant scientist, pathogenesis and therapy working group

Johns Hopkins University, Baltimore, Maryland, USA

W B GREENOUGH III, MD, FACP, member of the division of geographic medicine (currently seconded to ICDDR, B)

University of Gothenburg, S-413 46 Gothenburg, Sweden

J HOLMGREN, MD, professor of medical microbiology

London School of Hygiene and Tropical Medicine, London WC1E 7HT

B KIRKWOOD, MA, MSC, research fellow, medical statistics and epidemiology
These findings confirm the effectiveness of chlorpromazine in reducing fluid loss in cholera. A sedative effect, however, especially in children, may limit its usefulness and requires further study.

\section{Introduction}

Of all enteric pathogens that produce acute diarrhoea in man, Vibrio cholerae induces the most dramatic illness. The mortality rate in untreated cases may be $50-70 \%{ }^{12}$ The primary cause of death in cholera is dehydration, which in mild and moderate cases may be effectively treated with oral glucose-electrolyte solution; severely dehydrated patients with intense purging, however, require intravenous fluid. ${ }^{3}{ }^{4}$ Drugs that would reduce the rate of fluid loss in cholera have been sought with a view to decreasing the need for intravenous fluid. Several drugs have been tested in animals and found to have antisecretory properties. ${ }^{5}$

The mechanism of fluid loss in cholera includes the production of a toxin by $V$ cholerae which stimulates the activity of cellular adenylate cyclase in the intestine and increases the intraepithelial concentration of cyclic adenosine monophosphate. ${ }^{6-11}$ Chlorpromazine effectively inhibits adenylate cyclase activity in various tissues. ${ }^{12-14}$ In mice chlorpromazine reversed intestinal secretion induced by cholera toxin, heat labile Escherichia coli enterotoxin, or prostaglandin $E_{1}$, and in piglets the drug inhibited diarrhoea caused by toxicogenic $E$ coli $^{15-17}$ Furthermore, a preliminary study in patients with severe cholera also indicated that chlorpromazine reduced fluid loss by inhibiting intestinal secretion. We therefore decided to see whether the antisecretory effect of chlorpromazine in patients with cholera would be manifested in a larger, randomised controlled clinical trial and also if the drug would have an influence on other aspects of the disease such as vomiting and the duration of diarrhoea.

\section{Subjects and methods}

Adult male patients referred to the International Centre for Diarrhoeal Disease Research, Dacca, during August 1978 to December 1979 and who met the following criteria were considered for the study: (a) a history of watery diarrhoea for less than $\mathbf{4 8}$ hours, (b) $V$ cholerae in the stool as judged from dark-field microscopy, ${ }^{18}(c)$ severe dehydra- 
tion, and $(d)$ no history of current antibiotic use. Patients who gave voluntary informed consent were admitted to the study. After admission patients were rehydrated and fluid balance maintained using intravenous solution containing (per litre) $134 \mathrm{mmol}$ (mEq) sodium, $13 \mathrm{mmol}(\mathrm{mEq})$ potassium, $99 \mathrm{mmol}(\mathrm{mEq})$ chloride, and $48 \mathrm{mmol}(\mathrm{mEq})$ acetate until diarrhoea stopped. Antibiotics and oral rehydration solutions were not given.

The volumes of stool output, urine, and vomit and intake of intravenous fluid and drinking water were recorded every 12 hours. Blood tests for specific gravity, packed cell volume, and serum electrolyte concentrations were done on admission, at 24 hours, and on discharge. Hourly records of blood pressure (lying and standing), clinical vital signs, and state of consciousness were made in the chlorpromazine-treated and control patients. Rectal swabs were taken each morning for isolating $V$ cholerae by standard methods. ${ }^{19-21}$

Patients who continued to have diarrhoea (over $200 \mathrm{ml} /$ hour) 16 hours after admission were allocated at random to one of four chlorpromazine-treatment groups or to a control group; a table of randomised numbers was used. The four treatment groups received either 1 or $4 \mathrm{mg}$ of the drug/kg body weight given as a single dose either by mouth or intramuscularly. For the injections and oral administration chlorpromazine was supplied in glass ampoules and syrup bottles, respectively (Hibernal, AB Leo, Helsingborg, Sweden). After administration the patients were observed for 32 hours. Control patients were similarly observed but not given chlorpromazine; nor were they given a placebo. Nevertheless, chlorpromazine was administered to patients in the treatment groups by the attending physicians without the knowledge of staff responsible for collecting, measuring, and recording the volumes of stool, urine, and vomit. During working hours the staffs were randomly rotated in eight-hour shifts between different wards.

A total of 46 patients were studied: nine were included in each of the treatment groups given $4 \mathrm{mg} / \mathrm{kg}$ by mouth, $4 \mathrm{mg} / \mathrm{kg}$ intramuscularly, and $1 \mathrm{mg} / \mathrm{kg}$ intramuscularly; seven were in the group given $1 \mathrm{mg} / \mathrm{kg}$ by mouth; and 12 served as controls.

Reduction in fluid loss after chlorpromazine was expressed as a percentage of the 16-hour basal rate-that is, the rate during the 16 hours before allocation to treatment-and compared with that in the controls for each consecutive eight-hour period from 16 hours after admission. Due to the wide variation in purging rate after chlorpromazine a logarithmic transformation was applied to stabilise the variances and all analyses carried out using transformed values. For each time period the purging rates of the five groups were compared using one-way analysis of variance. Data for the control and the treatment groups were also compared in relation to duration of diarrhoea, intravenous fluid requirements, frequency of vomiting, and clinical findings.

\section{Results}

Table I gives the clinical characteristics of patients in the control and four treatment groups. The groups were similar in age, sex, distribution, and other clinical variables. After intravenous rehydration patients were well maintained in fluid balance, as indicated by weight gain, urine output, and follow-up measurements of serum specific gravity.

\section{STOOL REDUCTION}

Figure 1 shows the reduction in stool output of the chlorpromazinetreated and control patients. Over the 16 hours before administration of chlorpromazine (not shown in fig 1) the mean basal rates of purging $( \pm S E M)$ were similar in the drug-treated groups-430 $1111 \mathrm{ml}$ (1 $\mathrm{mg} / \mathrm{kg}$ by mouth), $537 \pm 57 \mathrm{ml}(4 \mathrm{mg} / \mathrm{kg}$ by mouth), $579 \pm 83 \mathrm{ml}$ (1

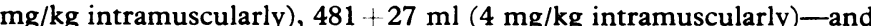
$500 \pm 67 \mathrm{ml}$ in the control group. During the first, second, and fourth eight-hour periods after chlorpromazine the purging rates in the combined four treatment groups were significantly lower than in the controls ( $p<0.005, p<0.05$, and $p<0.01$, respectively). In the third eight-hour period, however, the difference between the treatment and control groups was not significant. Though differences between the four treatment groups were not significant, there was a tendency for a better effect with the higher dose $(4 \mathrm{mg} / \mathrm{kg})$ of chlorpromazine given by either route.

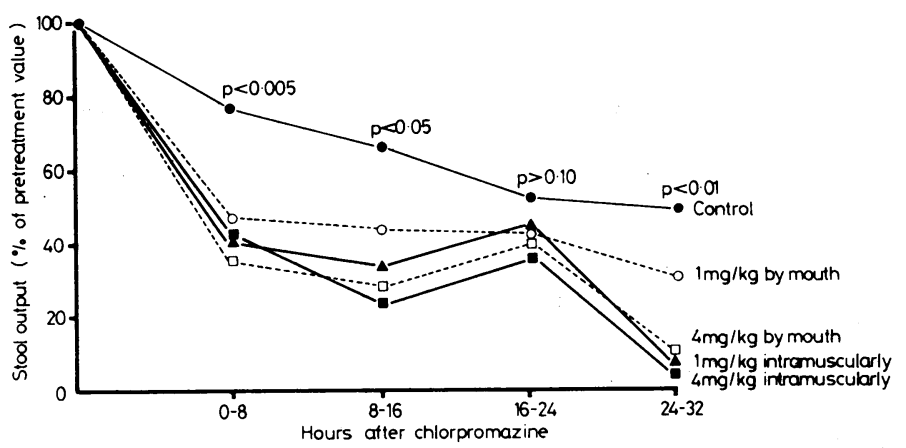

FIG 1-Fluid losses in chlorpromazine-treated and control patients with cholera. Rate of stool output expressed as percentage of output before chlorpromazine during successive eight-hour periods from time of administration. Geometric mean values for different treatment groups ( 1 or 4 $\mathrm{mg}$ chlorpromazine/kg by mouth or intramuscularly) compared with corresponding values for controls studied during same period of illness but not given chlorpromazine.

Figure 2 shows the specific reductions in stool output of each chlorpromazine-treated group. These reductions were calculated by subtracting the percentage reductions in purging rate of the treatment groups from those of the control group during the corresponding periods. In patients given chlorpromazine by either route the drug produced a striking biphasic inhibition with separate peaks during the first and fourth eight-hour periods after administration.

Of all the patients treated with chlorpromazine either by mouth or intramuscularly, 20 ( 11 given $4 \mathrm{mg} / \mathrm{kg}$; nine given $1 \mathrm{mg} / \mathrm{kg}$ ) had basal purging rates exceeding $100 \mathrm{ml} / \mathrm{kg} / 8$ hours, which would have been difficult to balance with oral fluids alone. Within the first eight hours after the drug, however, 16 of these patients (nine given $4 \mathrm{mg} / \mathrm{kg}$; seven given $1 \mathrm{mg} / \mathrm{kg}$ ) had rates below $75 \mathrm{ml} / \mathrm{kg} / 8$ hours, which are almost always managed successfully with oral treatment. Out of nine control

TABLE I-Clinical characteristics and results of laboratory investigation of chlorpromazine-treated and control patients (values are means \pm SD)

\begin{tabular}{|c|c|c|c|c|c|}
\hline \multirow[b]{2}{*}{ Characteristics } & \multicolumn{4}{|c|}{ Chlorpromazine-treated groups } & \multirow[b]{2}{*}{$\begin{array}{l}\text { Controls } \\
(n=12)\end{array}$} \\
\hline & $\begin{array}{l}\mathbf{4 ~ m g} / \mathbf{k g} \\
\text { intramuscularly } \\
(\mathrm{n}=9)\end{array}$ & $\begin{array}{l}4 \mathrm{mg} / \mathrm{kg} \\
\text { by mouth } \\
(\mathrm{n}=9)\end{array}$ & $\begin{array}{c}1 \mathrm{mg} / \mathrm{kg} \\
\text { intramuscularly } \\
(\mathrm{n}=9)\end{array}$ & $\begin{array}{c}1 \mathrm{mg} / \mathrm{kg} \\
\text { by mouth } \\
(\mathrm{n}=7)\end{array}$ & \\
\hline $\begin{array}{l}\text { Age (years) } \\
\text { Before admission: }\end{array}$ & $29 \cdot 5 \pm 8 \cdot 5$ & $28 \cdot 9 \pm 6 \cdot 8$ & $27 \cdot 6 \pm 5 \cdot 6$ & $30 \cdot 4 \div 7 \cdot 4$ & $31 \cdot 3 \pm 3 \cdot 2$ \\
\hline $\begin{array}{l}\text { Duration of diarrhoea (hours) } \\
\text { No of times stool passed } \\
\text { No of times vomited }\end{array}$ & $\begin{array}{r}12 \cdot 4 \pm 3 \cdot 8 \\
8 \cdot 5 \pm 6 \cdot 3 \\
8 \cdot 4 \pm 3 \cdot 8\end{array}$ & $\begin{array}{r}14 \cdot 8 \pm 4 \cdot 5 \\
10 \cdot 8 \pm 7 \cdot 4 \\
4 \cdot 8 \pm 2 \cdot 7\end{array}$ & $\begin{array}{l}13 \cdot 2 \pm 4 \cdot 7 \\
12 \cdot 5 \pm 6 \cdot 8 \\
10 \cdot 8 \pm 6 \cdot 5\end{array}$ & $\begin{array}{r}14 \cdot 7 \pm 5 \cdot 3 \\
10 \cdot 4+8 \cdot 0 \\
6 \cdot 0 \pm 4 \cdot 3\end{array}$ & $\begin{array}{r}14 \cdot 5 \pm 3 \cdot 6 \\
8 \cdot 6 \pm 5 \cdot 3 \\
7 \cdot 6 \pm 4 \cdot 8\end{array}$ \\
\hline $\begin{array}{l}\text { On admission: } \\
\text { Body weight (kg) } \\
\text { Plasma specific gravity } \\
\text { Blood packed cell volume (\%) } \\
\text { Body weight loss }(\%)\end{array}$ & $\begin{array}{c}42 \cdot 1 \pm 3 \cdot 8 \\
1 \cdot 028 \pm 0 \cdot 003 \\
42 \cdot 0 \pm 3 \cdot 5 \\
9 \cdot 0 \pm 1 \cdot 3\end{array}$ & $\begin{array}{c}41 \cdot 1 \pm 4 \cdot 3 \\
1 \cdot 029 \pm 0 \cdot 002 \\
40 \cdot 6 \pm 6 \cdot 3 \\
8 \cdot 2 \pm 1 \cdot 4\end{array}$ & $\begin{array}{c}42 \cdot 0 \pm 4 \cdot 9 \\
1 \cdot 028 \pm 0 \cdot 002 \\
38 \cdot 3 \pm 7 \cdot 4 \\
9 \cdot 2 \pm 1 \cdot 5\end{array}$ & $\begin{array}{c}40 \cdot 3+3 \cdot 2 \\
1 \cdot 029+0 \cdot 002 \\
43 \cdot 1+6 \cdot 3 \\
8 \cdot 3 \pm 1 \cdot 3\end{array}$ & $\begin{array}{c}40 \cdot 6 \pm 2 \cdot 9 \\
1 \cdot 027+0 \cdot 003 \\
40 \cdot 2+5 \cdot 6 \\
9 \cdot 2 \pm 1 \cdot 1\end{array}$ \\
\hline $\begin{array}{l}\text { After admission: } \\
\text { Weight gain }(\%) \text { at } 24 \text { hours } \\
\text { At discharge } \\
\text { Urine output (1) }\left\{\begin{array}{l}0-16 \text { hours } \\
16-32 \text { hours }\end{array}\right. \\
\text { Plasma specific gravity }\left\{\begin{array}{l}8 \text { hours } \\
24 \text { hours }\end{array}\right.\end{array}$ & $\begin{array}{c}10.3 \pm 1.2 \\
9 \cdot 5 \pm 1.5 \\
0.41 \pm 0.08 \\
0.83 \pm 0.15 \\
1.026 \pm 0.002 \\
1.025 \pm 0.001\end{array}$ & $\begin{array}{c}9 \cdot 8 \pm 1 \cdot 3 \\
9 \cdot 2 \pm 1 \cdot 3 \\
0 \cdot 48 \pm 0 \cdot 06 \\
0.96 \pm 10 \cdot 15 \\
1 \cdot 027 \pm 0 \cdot 002 \\
1 \cdot 026 \pm 0.001\end{array}$ & $\begin{array}{c}10.4 \pm 1.8 \\
9 \cdot 2+1.3 \\
0.52 \pm 0.05 \\
0.86 \pm 0 \cdot 16 \\
1 \cdot 025 \pm 0.002 \\
1 \cdot 026 \pm 0.002\end{array}$ & $\begin{array}{c}9 \cdot 3+1 \cdot 2 \\
9 \cdot 1+1 \cdot 5 \\
0 \cdot 54+0 \cdot 10 \\
0 \cdot 98+0 \cdot 18 \\
1 \cdot 025+0 \cdot 002 \\
1 \cdot 025: 0 \cdot 002\end{array}$ & $\begin{array}{cl}9.2 & 1.3 \\
9 \cdot 7 & 1.3 \\
0.53 & 0.05 \\
0.90 & 0.12 \\
1.026 & 0.002 \\
1.026 & 0.001\end{array}$ \\
\hline
\end{tabular}




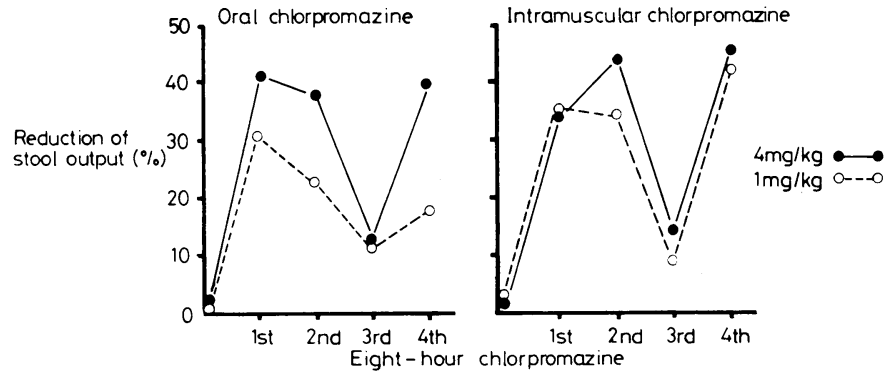

FIG 2-Specific stool reductions in chlorpromazine-treated groups. Chart shows differences in stool output between control and chlorpromazinetreated groups as percentage of initial 16-hour output rate (percentage reduction).

patients with high basal purging rates, only one showed such a reduction. This difference between the control and treatment groups was significant $(\mathrm{p}<0.02 ;$ Fisher's exact test).

DURATION OF DIARRHOEA, FREQUENCY OF VOMITING, AND INTRAVENOUS FLUID REQUIREMENT

Table II shows the duration of diarrhoea, frequency of vomiting, and requirement for intravenous fluid of patients in the treatment and control groups. After chlorpromazine the mean duration of diarrhoea was significantly reduced in each treatment group as compared with the duration in the controls $(p<0.001)$. Also in the treatment groups fewer patients vomited and the mean requirement for intravenous fluid per patient was significantly less than in the controls $(p<0.01)$.

TABLE II-Effect of chlorpromazine on duration of diarrhoea, frequency of vomiting, and intravenous fluid requirement

\begin{tabular}{|c|c|c|c|c|}
\hline \multirow{2}{*}{ Treatment groups } & \multirow{2}{*}{$\begin{array}{l}\text { Mean } \\
\text { duration of } \\
\text { diarrhoea } \\
\pm \text { SD } \\
\text { (hours)* }\end{array}$} & \multirow{2}{*}{$\begin{array}{l}\text { No }(\%) \text { of } \\
\text { patients } \\
\text { vomiting } \\
\text { within } \\
24 \text { hours of } \\
\text { chlorpro- } \\
\text { mazine } \dagger\end{array}$} & \multicolumn{2}{|c|}{$\begin{array}{l}\text { Requirement for } \\
\text { intravenous fluid } \\
\text { (1/patient } / 32 \text { hours }) \ddagger\end{array}$} \\
\hline & & & $\begin{array}{c}\text { Mean } \\
\text { total } \\
\text { intake } \pm S D\end{array}$ & $\begin{array}{c}\text { Mean } \\
\text { volume } \\
\text { saved } \pm S D\end{array}$ \\
\hline 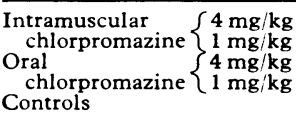 & $\begin{array}{l}94 \cdot 6 \pm 2 \cdot 4 \\
92 \cdot 1 \pm 2 \cdot 3 \\
97 \cdot 1 \pm 2 \cdot 5 \\
99 \cdot 0 \pm 3 \cdot 0 \\
135 \cdot 6 \pm 1 \cdot 9\end{array}$ & $\begin{array}{l}2 / 9(22) \\
1 / 9(11) \\
3 / 9(33) \\
3 / 7(43) \\
9 / 12(75)\end{array}$ & $\begin{array}{r}6 \cdot 48 \pm 1 \cdot 32 \\
8 \cdot 69 \pm 1 \cdot 45 \\
6.79 \pm 0.98 \\
6 \cdot 79 \pm 1 \cdot 24 \\
12 \cdot 10 \pm 1.94\end{array}$ & $\begin{array}{l}5.62 \pm 0.71 \\
3.41 \pm 0.73 \\
5.31 \pm 0.69 \\
5.31 \pm 0.79\end{array}$ \\
\hline
\end{tabular}
* Chlorpromazine-treated patients in each group showed significantly shorter duration of diarrhoea than cot

groups $5 \cdot 32$ to $8 \cdot 26$ ). controls $\left(p<0.001 x^{2}\right.$ test 8.77$)$.

controls ( $p<0.001 x^{2}$ test 8.77 ).
Significantly less intravenous fluid required in chlorpromazine-treated groups than in controls $(\mathrm{p}<0.01$ range of $t$-test values $4 \cdot 42$ to $7 \cdot 47)$

\section{CLINICAL EFFECTS}

The hypotensive effect of chlorpromazine was evaluated in nine well-hydrated patients given $4 \mathrm{mg} / \mathrm{kg}$ by mouth or intramuscularly. Before treatment the mean systolic and diastolic blood pressures were 130 and $85 \mathrm{~mm} \mathrm{Hg}$ respectively. During the first eight hours after chlorpromazine the lowest recorded readings were 125 and $80 \mathrm{~mm} \mathrm{Hg}$ respectively. The mean of the differences between horizontal and erect blood pressures also did not differ before and after administration of the drug ( $4 v 6 \mathrm{~mm} \mathrm{Hg}$ ). There was no appreciable change in radial pulse, respiratory rate, and oral temperature after any of the given doses of chlorpromazine.

\section{Discussion}

This study supports the preliminary observations on the antisecretory effect of chlorpromazine in patients with cholera. ${ }^{22}$ The drug, which effectively reduces fluid loss in mice and piglets, ${ }^{15-17}$ was also effective in man at comparable doses. The antisecretory effect of the drug began within two hours of administration and continued through the first two eight-hour periods. A second peak of inhibition was observed during the fourth eight-hour period (24-32 hours). This pattern of bimodal inhibitory response was seen in each of the four treatment groups. Though we cannot explain this biphasic response, the first peak probably reflects a toxin-antagonising effect of chlorpromazine, whereas the second may be due to the generation of some metabolite of the drug which also has antisecretory activity. ${ }^{23}$ Alternatively, the second peak might reflect the weak antibacterial action of chlorpromazine. Further studies will be needed to examine these hypotheses.

Though there was no significant difference in response between groups given $4 \mathrm{mg} / \mathrm{kg}$ and $1 \mathrm{mg} / \mathrm{kg}$, there was a tendency for a lower purging rate in the higher-dose group. This finding is consistent with the dose-response studies in animals: in mice $4 \mathrm{mg} / \mathrm{kg}$ gave complete and $1.5 \mathrm{mg} / \mathrm{kg}$ gave half-maximal inhibition of the secretory response to a high dose of cholera toxin. ${ }^{15}$

The mechanism by which chlorpromazine reduces fluid loss in cholera has not been established but may include inhibition of adenylate cyclase activity in the intestinal mucosa. ${ }^{315}$ There may, however, be other effects as well. ${ }^{15}$ Chlorpromazine reportedly modifies several cell membrane functions, such as expansion of the lipid bilayer and release of calcium ions. ${ }^{24}$ It also inhibits intestinal membrane protein kinase activities. ${ }^{15}$ All these effects, alone or in combination, may interfere with the membrane transport process. A unifying hypothesis linking the observed inhibition of adenylate cyclase activity to a postulated action of chlorpromazine on the calcium-binding protein calmodulin in intestine ${ }^{25}{ }^{26}$ has been advanced to explain the antisecretory effect. ${ }^{27}$

Our results indicate that chlorpromazine is also effective in reducing the duration of diarrhoea, frequency of vomiting, and requirements for intravenous fluid, which are important determinants of the disease. Use of the drug in cholera might therefore obviate the need for much intravenous fluid and simplify rehydration procedures, particularly in a rural outbreak. Children with intense vomiting are especially difficult to manage with oral rehydration fluids, and use of chlorpromazine in these cases may be more beneficial. The standard treatment of cholera, however, is still rehydration fluid and tetracycline, and whether chlorpromazine can further simplify these treatment procedures in a more practical way needs to be determined. Sedation from the drug could be one limitation of its usefulness. The sedative effect of chlorpromazine was manifested by mild drowsiness, which gradually improved over four to six hours. In children, however, an optimal antisecretory dose of the drug might produce stronger sedation and interfere with the intake of oral rehydration fluid. Hence the ability of chlorpromazine to reduce the failure rate in patients with cholera rehydrated by mouth, especially children, needs to be examined. Also, further studies to determine whether the antisecretory effect of the drug extends to non-cholera diarrhoea-for example, toxicogenic $E$ coli diarrhoea-would be particularly important, since $E$ coli is a major diarrhoeal agent in many parts of the world.

This work was jointly supported by the International Centre for Diarrhoeal Disease Research, Bangladesh; SAREC, Sweden; and the Swedish Medical Research Council.

Requests for reprints should be addressed to: G H Rabbani, ICDDR, B, GPO Box 128, Dacca-2, Bangladesh.

\section{References}

1 Benenson AS, ed. Cholera. In: Control of communicable diseases in man. 11th ed. New York: American Public Health Association, 1970:52. 2 Benenson AS, Islam MR, Greenough WB III. Rapid identification of Vibrio cholerae by darkfield microscopy. Bull WHO 1964;30:827-31.

${ }^{3}$ Nalin DR, Cash RA, Islam R, Molla M, Phillips RA. Oral maintenance therapy for cholera in adults. Lancet 1968 ;ii:370-3. 
4 Pierce NF, Sack RB, Mitra RC, et al. Replacement of water and electrolyte losses in cholera by an oral glucose-electrolyte solution. Ann Intern Med $1969 ; 70: 1173-81$.

5 Powell DW, Field M. Pharmacological approaches to treatment of secretory diarrhea. In : Field M, Fordtran JS, Schultz SG, eds. Secretory diarrhea. Bethesda, Maryland: American Physiological Society, 1980: 187-209.

${ }^{6}$ Field M, Fromm D, Al-Awqati Q, Greenough WB III. Effects of cholera enterotoxin on ion transport across isolated ileal mucosa. $\mathcal{f}$ Clin Invest $1972 ; 51: 796-804$.

7 Parkinson DK, Ebel H, DiBona DR, Sharp GWG. Localization of the action of cholera toxin on adenylate cyclase in mucosal epithelial cells of rabbit intestine. $\mathcal{F}$ Clin Invest 1972;51:2292-8.

${ }^{8}$ Schafer DE, Lust WD, Sircar B, Goldberg ND. Elevated concentration of adenosine $3^{\prime}$ : $5^{\prime}$-cyclic monophosphate in intestinal mucosa after treatment with cholera toxin. Proc Natl Acad Sci USA 1970;67:851-6.

9 Sharp GWG, Hynie S. Stimulation of intestinal adenylate cyclase by cholera toxin. Nature $1971 ; 559: 266-9$.

10 Field $M$. Intestinal secretion and its stimulation by enterotoxins. In: Ouchterlony Ö, Holmgren J, eds. Cholera and related diarrheas: 43rd Nobel symposium, Stockholm, 1978. Basle: Karger, 1980:46-52.

${ }^{11} \mathrm{Kimberg}$ DV. Cyclic nucleotides and their role in gastrointestinal secretions. Gastroenterology 1974;67:1023-64.

12 Kakiuchi S, Rall TW. The influence of chemical agents on the accumulation of adenosine $3^{\prime}, 5^{\prime}$-phosphate in slices of rabbit cerebellum. Mol Pharmacol 1968;4:367-78.

13 Osnes JB, Christoffersen T, Morland J, Oye I. Chlorpromazine and hormonal elevation of cyclic AMP contents in turkey erythrocytes and in perfused rat heart and liver. Acta Pharmacol Toxicol (Copenh) 1976; 38:195-208.

14 Wolff J, Jones AB. Inhibition of hormone-sensitive adenylate cyclase by phenothiazines. Proc Natl Acad Sci USA 1970;65:454-9.

15 Holmgren J, Lange S, Lönnroth I. Reversal of cyclic AMP mediated intestinal secretion in mice by chlorpromazine. Gastroenterology 1978 75:1103-8.

${ }^{16}$ Lönnroth I, Holmgren J, Lange S. Chlorpromazine inhibits cholera toxin induced intestinal hypersecretion. Med Biol 1977;55:126-9.

17 Lönnroth I, Andrén B, Lange S, Martinsson K, Holmgren J. Chlorpromazine reverses diarrhea in piglets caused by enterotoxigenic Escherichia coli. Infect Immun 1979;24:900-5.

18 Anonymous. Cholera again. Br Med f 1970;iv:2-3.

19 Finkelstein RA, Mukherjee S. Hemagglutination: a rapid method for differentiating Vibrio cholerae and El Tor vibrios. Proc Soc Exp Biol Med 1963;112:355-9.

${ }^{20}$ Feeley JC. Isolation of cholera vibrios by positive-recognition plating procedures. $\mathcal{f}$ Bacteriol $1962 ; 84: 866-7$.

${ }^{21}$ Smith HL Jr, Goodner K. On the classification of vibrios. Proceedings of the cholera research symposium. Washington DC: US Government Printing Office, 1965:4-8. (Public Health Service publication No 1328.)

${ }^{22}$ Rabbani GH, Holmgren J, Greenough WB III, Lönnroth I. Chlorpromazine reduces fluid loss in cholera. Lancet $1979 ; \mathrm{i}: 410-2$.

${ }^{23}$ Williams RT, Parke DV. The metabolic fate of drugs. Annual Review of Pharmacology $1964 ; 4: 85-114$.

24 Seeman $P$. The membrane actions of anaesthetics and tranquilizers. Pharmacol Rev 1972;24:583-655.

${ }^{25}$ Ilundain A, Naftalin RJ. Role of $\mathrm{Ca}^{2+}$-dependent regulator protein in intestinal secretion. Nature $1979 ; 279: 446-8$.

${ }^{26}$ Smith PL, Field $M$. In vitro antisecretory effects of trifluoperazine and other neuroleptics in rabbit and human small intestine. Gastroenterology $1980 ; 78: 1545-53$.

27 Holmgren J, Greenough WB III. New perspectives in the treatment and prophylaxis of diarrhoeal diseases. In: Holme $T$, Holmgren $J$, Merson MH, Möllby $\mathrm{R}$, eds. Acute enteric infections in children: new prospects for treatment and prevention. Amsterdam: Elsevier NorthHolland Biomedical Press, 1981:341-54.

(Accepted 11 February 1982)

\section{OF FEVERS IN GENERAL.}

AS more than one half of mankind is faid to perifh by fevers, it is of importance to be acquainted with their caufes. The moft general caufes of fevers are, infection, errors in diet, unwholefome air, violent emotions of the mind, Suppreffion of ufual evacuations, external or internal injuries, and extreme degrees of heat or cold. As moft of thefe have already been treated of at confiderable length, and their effects fhewn, we shall not now refume the confideration of them, but fhall only recommend it to all, as they would wifh to avoid fevers and other fatal difeafes, to pay the moft punctual attention to thefe articles.

FEVERS are not only the moft frequent of all difeafes, but they are likewife the moft complex: In the moft fimple fpecies of fever there is always a combination of feveral different fymptoms. The diftinguifhing fymptoms of fever are, increafed heat, frequency of pulfe, lofs of appetite, general debility, pain in the head, and a difficulty in performing fome of the vital or animal functions. The other fymptoms ufually attendant on fevers are, naufea, thirft, anxiety, wearinefs, wafting of the flefh, want of fleep, or the fleep difturbed and not refrefhing.

WHEN the fever comes on gradually, the patient generally complains firft of languor or liftleffnefs, forenefs of the flef h, or the bones, as the country people exprefs it, heavinefs of the head, lofs of appetite, ficknefs, with clamminefs of the mouth; after fome time come on exceffive heat, violent thirft, reftleffnefs, \&c.

WHEN the fever attacks fuddenly, it always begins with an uneafy fenfation of exceffive cold, accompanied with debility and lofs of appetite; frequently the cold is attended with fhivering, oppreffion about the heart, and ficknefs at ftomach, or vomiting.

FEVERS are divided into continual, remitting, intermitting, and fuch as are attended with cutaneous eruption or topical inflammation, as the fmall-pox, eryfipelas, \&c. By a continual fever is meant that which never leaves the patient during the whole courfe of the difeafe, or which hews no remarkable increafe or abatement in the fymptoms. This kind of fever is likewife divided into acute, flow, and malignant. The fever is called acute when its progrefs is quick, and the fymptoms violent; but when thefe are more gentle, it is generally denominated Slow. When livid or petechial fpots fhew a putrid ftate of the humours, the fever is called malignant, putrid, or petechial.
A remitting fever differs from a continual only in degree. It has frequent increafes and decreafes, or exacerbations and remiffions, but never wholly leaves the patient during the courfe of the difeafe. Intermitting fevers, or agues, are thofe which, during the time that the patient may be faid to be ill, have evident intervals or remiffions of the fymptoms.

A s a fever is only an effort of Nature to free herfelf from an offending caufe, it is the bufinefs of thofe who have the care of the fick, to obferve with diligence which way Nature points, and to endeavour to affift her operations. Our bodies are fo framed, as to have a conftant tendency to expel or throw off whatever is injurious to health. This is generally done by urine, fweat, ftool, expectoration, vomit, or fome other evacuation.

MANY of thofe who follow fedentary employments are conftantly in a bending pofture, as fhoemakers, taylors, cutlers, \&c. Such a fituation is extremely hurtful. A bending pofture obftructs all the vital motions, and of courfe muft deftroy the health. Accordingly we find fuch artificers generally complaining of indigertions, flatulencies, head-achs, pains of the breaft, \&c.

THE aliment in fedentary people, inftead of being pufhed forwards by an erect pofture, and the action of the mufcles, is in a manner confined in the bowels. Hence indigeftions, cortivenefs, wind, and other hypochondriacal affections, the conftant companions of the fedentary. Indeed none of the excretions can be duly performed where exercife is wanting; and when the matter which ought to be difcharged in this way, is retained too long in the body, it muft have bad effects, as it is again taken up into the mafs of humours.

A BENDING pofture is likewife hurtful to the lungs. When this organ is compreffed, the air cannot have free accefs into all its parts, fo as to expand them properly. Hence tubercles, adhefions, \&c. are formed, which often end in confumptions. Befides, the proper action of the lungs being abfolutely neceffary for making good blood, when that organ fails, the humours foon become univerfally depraved, and the whole conftitution goes to wreck. (Buchan's Domestic Medicine, 1786.) 